\section{G}

Entrepreneurial Business and Economics Review

2020, Vol. 8, No. 1

\title{
How Absorptive Capacity and Organisational Learning Orientation Interact to Enable Innovation Capability? An Empirical Examination
}

\author{
Monika Stelmaszczyk
}

\begin{abstract}
A B S T R A C T
Objective: The main objective of the article is to examine the effect of organisational learning orientation (OLO) and absorptive capacity (AC) on innovation capability (IC).

Research Design \& Methods: The hypotheses were tested on a sample of 239 respondents. Hypotheses were verified by means of structural equation modelling (SEM), using the asymptotically distribution-free method (ADF).

Findings: A change in organisational learning orientation brings about changes in absorptive capacity, which in turn influences business innovation capability. Absorptive capacity is affected mostly by two dimensions of organisational learning orientation: commitment to learning (OLO1) and open-mindedness (OLO3). In turn, absorptive capacity affected by organisational learning orientation has the strongest impact on product innovation (IC1), a lesser impact on process innovation (ICA2), and the weakest impact on managerial innovation (IC3). Moreover, the process of knowledge sharing (KS) mediates the effect of absorptive capacity on each of the dimensions of innovation capability.
\end{abstract}

Implications \& Recommendations: First, this study expands our understanding of the effect of learning orientation on absorptive capacity. Second, it confirms the presence of a statistically significant and positive relationship between absorptive capacity and innovation capability. The third implication concerns the indirect dependencies between absorptive capacity and innovation capability.

Contribution \& Value Added: The study identifies and examines mechanisms that support the transformation of external knowledge - already acquired and used by an organisation - into innovations.

\begin{tabular}{|c|c|}
\hline Article type: & $\begin{array}{l}\text { research article } \\
\text { absorptive capacity; innovation capability; organisational learning ori- } \\
\text { entation; knowledge sharing; SEM }\end{array}$ \\
\hline JEL codes: & D83, D23, D24, E22, L10, M10, O30 \\
\hline Received: 29 & Accepted: 23 March 2020 \\
\hline
\end{tabular}

\section{Suggested citation:}

Stelmaszczyk, M. (2020). How Absorptive Capacity and Organisational Learning Orientation Interact to Enable Innovation Capability? An Empirical Examination. Entrepreneurial Business and Economics Review, 8(1), 7-32. https://doi.org/10.15678/EBER.2020.080101 


\section{INTRODUCTION}

In the last three decades, the literature on strategic management has emphasised the importance of knowledge in building and maintaining a competitive advantage (Wang, $\mathrm{He}, \&$ Mahoney, 2009). In this context, innovation capability - in which knowledge plays a special meaning - is also brought to the forefront. Currently, enterprises increasingly build their innovation capability based on external sources of knowledge (Laursen \& Salter, 2006; Newey \& Verreynne, 2011). However, key external knowledge is often not easily available (Argote, 2013; Baum, Lööf, \& Nabavi, 2019). Moreover, external knowledge enhances the need for the creation of internal knowledge (Nonaka, 1994; Grigoriou, \& Rothaermel, 2017). Thus, when we take both sources of knowledge into consideration, absorptive capability becomes the key tool in the process. Absorptive capability involves the ability to acquire and use knowledge available outside of the organisation (Tortoriello, 2015). Absorptive capability is manifested through the organisation's ability to value, assimilate, and apply new knowledge. The ability to value new knowledge is shaped on the basis of existing experience and commitment. The ability to assimilate knowledge depends on the kind of knowledge, characteristics of the organisation or organisational alliances, and technological overlap. On the other hand, the ability to apply knowledge is affected by technological opportunity - the amount of relevant external knowledge - and appropriability, i.e. the ability to protect innovation (Cohen \& Levinthal, 1990).

An organisation in possession of a well-developed absorptive capacity can recognise valuable knowledge coming from the outside, assimilate it, and apply it in the development of innovation (Cohen et. al., 1990). Many researchers believe that absorptive capacity plays a key role in the creation and implementation of valuable innovations (Volberda, Foss, \& Lyles, 2010; Huang, Rice, \& Martin, 2015). According to some researchers, absorptive capacity in the creation of innovation capability of enterprises is continually gaining importance (Peeters, Massini, \& Lewin, 2014). However, Wales, Parida, and Patel (2013) show that, in certain circumstances, absorptive capacity can lead to poor performance.

Therefore, studying direct relationships between absorptive capacity and innovations or innovation capability can give an incomplete picture of this dependency (Volberda et al., 2010). Thus, we should investigate the factors that shape the impact of absorptive capacity on innovation capability (Lane, Koka, \& Pathak, 2006). However, surprisingly few analyses determine the place and role of strategic orientation in models to test relationships between absorptive capacity and innovation capability, which results in a research gap.

Among various strategic orientations, the organisational learning orientation is extremely important. Its importance lies in the fact that there is a direct relationship between itself and absorptive capacity (Kim, 1998; Lichtenhalter, 2009). However, in strategic management, the most valuable knowledge is the knowledge of cause and effect within a given process. The awareness of this fact allows us to gain a better understanding of the process under scrutiny. Hence, a deeper and more holistic diagnosis of the relationship between the variables requires an examination of cause-and-effect relationships. Therefore, if it turns out that within the same research model organisational learning orientation affects absorptive capacity and, in turn, absorptive capacity affects innovation capability, then these influences can be understood as the effects of the process. Any change to organisational learning orientation - due to its potential impact on absorptive capacity - will 
thereby cause a change in absorptive capacity. In turn, any change in absorptive capacity can result in a change in innovation capability. Therefore, we should assume that organisational learning orientation has been the missing link in the study of the cause-and-effect relationship between absorptive capacity and innovation capability.

The purpose of this study is to identify the cause-and-effect relationships that occur among organisational learning orientation, absorptive capacity, and the organisation's innovation capability. The added value of this study is the enrichment of the literature on strategic management with a discussion of the relationship between absorptive capacity and innovation capability, while taking into account organisational learning orientation as the cause of the process.

The hypotheses were tested on a sample of 239 respondents who are employees of one of the largest Polish insulated glass manufacturers. The hypotheses will be verified by means of structural equation modelling (SEM), using the asymptotically distributionfree method (ADF).

We will present the theoretical framework and hypotheses, then describe the research objective (object) and research methods so as to, finally, present the findings of the empirical research, discuss them, and conclude.

\section{LITERATURE REVIEW}

\section{Absorptive Capacity}

The concept of absorptive capacity was first introduced by Kedia and Bhagat (1988) in the context of research on international technology transfer. However, Cohen and Levinthal (1989) were the first to note that absorptive capacity results from the recognition of the value of knowledge existing in the environment surrounding an organisation, its assimilation and application to achieve given aims. Cohen and Levinthal's study $(1989 ; 1990)$ is now considered the foundation of the existing research on the subject. In their view, absorptive capacity is "the ability of a business to recognise the value of new, external information, assimilate it, and apply it to commercial ends" (Cohen \& Levinthal 1990, p.128).

Lane et al. (2006) present an alternative definition of absorptive capacity. They revitalise the concept of absorptive capacity and eliminate possible deviations from its actual meaning. They claim that,

absorptive capacity is a firm's ability to utilise externally held knowledge through three sequential processes: (1) recognizing and understanding potentially valuable new knowledge outside the enterprises through exploratory learning, (2) assimilating valuable new knowledge through transformative learning, and (3) using assimilated knowledge to create new knowledge and commercial outputs through exploitative learning (Lane et al., 2006, p. 856).

Zahra and George (2002) note that absorptive capacity is also "the set of strategic organisational routines and processes that make it possible for enterprises to acquire, assimilate, transform and exploit knowledge to create dynamic capabilities." The classification of dimensions of absorptive capacity proposed by Zahra and George is widely accepted and adopted by other researchers (for example Wales et al., 2013). Zahra and 
George define absorptive capacity with four dimensions: a) the acquisition of general external knowledge, b) assimilation involving the analysis and understanding of the information coming from external sources, $c$ ) transformation through which current knowledge is combined with newly acquired and assimilated knowledge, and d) exploitation that allows for an expansion of existing competences or creation of new ones thanks to the use of the already acquired and transformed knowledge (Zahra \& George, 2002, pp. 185-203).

These definitions of absorptive capacity clearly focus on external knowledge and information. Therefore, this paper assumes that absorptive capacity is the ability of business to acquire, assimilate, transform, and exploit external knowledge.

\section{Absorptive Capacity in the Context of Organisational Learning Orientation}

The postulates proposed by Cohen and Levinthal (1990) indicate that with the growth of investment in research and development (R\&D), an organisation increases its ability to acquire and use external knowledge. In turn, this knowledge enhances the growth of an enterprise's innovation. On the other hand, the relationship between R\&D and absorptive capacity is accompanied by an implicit belief that external knowledge can be easily assimilated and transformed into organisational innovation. In other words, the main conclusion drawn from this analysis is that while investments in R\&D are made with the aim to generate innovation, an important by-product of these actions is the increase in a firm's capabilities to assimilate and exploit externally available information, i.e. the increase in absorptive capacity (Cohen \& Levinthal, 1989, p. 592). To this end, Cockburn and Henderson (1998) present the prospect of innovation development based on the absorptive capacity of pharmaceutical enterprises.

The results of subsequent studies generally confirm the existence of a relationship between absorptive capacity and innovation (e.g. Lenox \& King, 2004; Penner-Hahn \& Shaver, 2005; Mamun, Fazal, \& Mohiuddin, 2019). However, the researchers see absorptive capacity primarily in the light of the amount of funds invested in R\&D (Lane, Salk, \& Lyles, 2001), thereby indicating that the growth of such investments is accompanied by an increasing number of innovations. However, special attention paid to investments in $R \& D$ causes other important aspects of the assimilation and use of external business knowledge to disappear in the background (see, for example, Lane et al., 2006). Only a small number of studies highlight mechanisms that allow organisations to identify, assimilate, and use knowledge to enhance innovation, as shown by Volberda et al. (2010) who conducted a comprehensive bibliometric analysis of 1213 papers. In their view, there is a need to organise further research on absorptive capacity to fill the observed research gaps. One such research gap concerns a thorough examination of the building blocks that form absorptive capacity and a search for drivers that cause it to grow. Lane et al. (2006), Volberda et al. (2010) and Tortoriello (2015) claim that, until now, the mechanisms that transform the already acquired and applied external knowledge into innovations have been neither sufficiently recognised nor examined.

However, I suggest that the impact of absorptive capacity on enterprises' innovation capability can be reinforced by strategic orientation. In management sciences - in particular, in strategic management - an orientation of this kind can define the directions of an enterprise's actions (Miles \& Arnold, 1991, p. 49) Thus, bearing in mind the relationship between the already possessed knowledge and absorptive capacity (Feng et al., 2014) 
and the relationship between absorptive capacity and innovation (Patel et al., 2015), organisational learning orientation can be a guiding force for the impact of absorptive capacity on innovation capability. An organisational learning orientation covers the activities undertaken by the entire organisation in order to generate and apply knowledge to increase competitive advantage (Panayides, 2007). Organisational learning orientation also affects the type of information collected and the way it is evaluated, interpreted, and shared (Gutierrez, Bustinza, \& Molina, 2012). The definition of organisational learning orientation used herein is that proposed by Calantone, Cavusgil, and Zhao (2002): the "organisation-wide activity of creating and using knowledge to enhance competitive advantage" (Calantone, Cavusgil, \& Zhao, 2002, p. 516).

Organisational learning orientation significantly affects many aspects of an organisation's operations (Jerez-Gómez, Céspedes-Lorente, \& Pérez-Valls, 2017; Guinot, Chiva, \& Mallén, 2013). It can also affect absorptive capacity. Lichtenhalter (2009) defines exploratory learning as knowledge acquisition and believes that exploratory learning corresponds to the notion of potential absorptive capacity. Meanwhile, exploitative learning includes knowledge assimilation and exploitation, which jointly reflect the concept of realised absorptive capacity. Moreover, Kim (1998) notices dependencies between organisational learning and absorptive capacity. In his view, organisational learning is a function of absorptive capacity. He notes that "absorptive capacity requires learning capability and develops problem-solving skills. Learning capability is the capacity to assimilate knowledge (for imitation), whereas the problem-solving skills represent a capacity to create new knowledge (for innovation)" (Kim, 1998, p. 507). Kim's theoretical considerations were backed by empirical research at Hyundai Motor Enterprise, which established a strategy to develop absorptive capacity by strengthening learning orientation. Therefore, on the basis of previous studies' results, we may assume that organisational learning orientation not only affects absorptive capacity directly but can also affect the logical relationship between this variable and other phenomena. However, little attention is paid to the analysis of the impact of this orientation on absorptive capacity that in turn affects innovation capability. Hence the desire to discover whether this orientation affects absorptive capacity by means of applying innovation capability within the model. The question that arises is as follows: does absorptive capacity need organisational learning orientation in order to create innovation capabilities?

We adopt a view that promotes strategic orientation multidimensionality, represented by other researchers. In these conceptualisations, organisational learning orientation is a multidimensional construct (e.g. Baker \& Sinkula, 1999; Wang, 2008; Farkas, 2016). This means that organisational learning can be described using few perspectives. Baker and Sinkula (1999) foreground commitment to learning, shared vision, and open-mindedness. This approach enables a deeper insight into the nature of the phenomenon and the impact of organisational learning orientation on the specified reference point, i.e. absorptive capacity. On the basis of the above arguments, I propose the following hypotheses:

H1a: There is a positive relationship between commitment to learning and absorptive capacity.

H1b: There is a positive relationship between shared vision and absorptive capacity.

H1c: There is a positive relationship between open-mindedness and absorptive capacity. 
In organisations involved in learning, managers support learning at every level. They constantly gather pieces of information and analyse them. If there were no such involvement, organisational learning would be on a much lower level (Feng, Zhao, \& Su, 2014). The second dimension is associated with the shared vision and objectives of managers and employees. Without a shared vision and objectives, learning motivation will remain at low levels. Employees may not even be aware of what they have to learn (Wang, 2008). Having a shared vision orientates the learning process, while the last dimension, open-mindedness, affects learning intensity (Baker et al., 1999). Thus, open-mindedness is conducive to organisational learning, because it involves the development of new skills and encourages rejecting old and useless knowledge (Sinkula, Baker, \& Noordewier, 1997, p. 309). Open-mindedness is a proactive feature, because it is based on the premise that since knowledge is not permanent, every organisation requires continuous development.

\section{Absorptive Capacity and Innovation Capability}

The authors of one of the first studies on absorptive capacity highlight a positive linear relationship among absorptive capacity, innovation capabilities, and business innovation performance (Cohen et al., 1990). The results of subsequent studies generally confirm these dependencies (Tsai, 2001a; Zahra et al., 2002; Fosfuri \& Tribó, 2008; Tortoriello 2015; Zou, Guo, \& Guo, 2017). Moreover, researchers show that innovation capability is an important predictor of success (Godart, Maddux, \& Shipilov, 2015). Furthermore, any scholars believe that absorptive capacity is not an end in itself. In their view, this ability mediates, moderates, or otherwise affects key business results (Rothaermel \& Alexandre, 2009; Fernhaber \& Patel, 2012). Meanwhile, Lewin, Massini, and Peeters (2011) indicate that absorptive capacity was initially viewed solely as a mediating or moderating factor for a variety of phenomena related to innovation or efficiency. Over time, absorptive capacity was seen instead as a moderator, a variable that acts directly on innovation. Therefore, absorptive capacity has long been considered a significant factor in business innovation activity (Cohen et al., 1989, 1990; Cockburn et al., 1998). Despite this, the following question remains a "black box:" what will be the influence of absorptive capacity on innovation capability if we assume that organisational learning orientation is the cause of the existence of absorptive capacity?

Organisations with a well-developed innovation capability demonstrate a willingness to introduce innovations and establish methods for their implementation (Samson \& Gloet, 2014, p. 6450; Krawczyk-Sokołowska, Pierścieniak, \& Caputa, 2019). Innovation capability is the ability to use a set of interrelated procedures to develop and implement new products and improve the quality of existing products (Wang et al., 2017). In other words, it is a philosophy of continuous improvement that holds a key role in business development (Subramaniam \& Youndt, 2005). It is the ability to create and implement new ideas resulting in innovation, whose spread brings benefits to the enterprise (Jain, 2013).

Moreover, based on the concept of innovation by Samson (1991), Tsai, Huang, and Kao (2001b) define innovation capability in terms of product innovation, process innovation, and managerial innovation. We adopt this approach in our study. Much research has been devoted to the influence of absorptive capacity on innovation (or innovation capability). Nevertheless, few empirical studies - if any at all - verify the influence of absorptive capacity on product innovation, process innovation, and managerial innovation (simultaneously taking into account the effect of organisational learning orientation on absorptive capacity). 
Scholars argue that absorptive capacity affects product innovation (Zhang, Zhao, \& Lyles, 2018; Moilanen, Østbye, \& Woll, 2014; Tavani, Sharifi, \& Ismail, 2014). Moreover, there exists empirical evidence that absorptive capacity affects process innovations (Aliasghar, Rose, \& Chetty, 2019; Najafi-Tavani et al., 2018). So far, the direct impact of absorptive capacity on innovation management rarely underwent academic scrutiny. Despite such drawbacks, Ali, Kan, and Sarstedt (2016) empirically confirm the existence of a relationship between the variables. Therefore, I propose the following hypotheses:

H2a: There is a positive relationship between absorptive capacity and product innovation.

H2b: There is a positive relationship between absorptive capacity and process innovation.

H2c: There is a positive relationship between absorptive capacity and managerial innovation.

Product innovations must be identified with the implementation of goods or services that are new or significantly improved (Müller-Stewens et al., 2017). Novelty or significant improvement is assessed from the perspective of functionality and the commercial end of a product or service. By contrast, process innovation is the implementation of a new or significantly improved production or delivery method (OECD, 2005; Vuori \& Huy, 2016). Process innovations may lower production or supply costs and improve quality. Process innovations provide new or significantly improved products and services. Meanwhile, managerial innovation is the ability through which an enterprise improves its performance. Managerial innovation allows for the introduction of new regulations, systems, or methods of management (Tsai et al., 2001b). In this way, knowledge about the development of managerial functions and mechanisms used by managers to improve managerial efficiency becomes innovation capability.

\section{The Role of Knowledge Sharing as a Mediator}

Despite previous studies devoted to the dependencies between absorptive capacity and innovation or innovation capability, surprisingly few studies demonstrate why there is such a regularity. Therefore, a deeper and more holistic understanding of this dependency requires paying attention to additional variables that can shape the relationship between absorptive capacity and innovation capability. Indicating the mediators of such dependencies will foster a better understanding of the studied phenomenon. It will alleviate difficulties in explaining why the phenomenon exists and how it functions. Indeed, mediation is one of the indirect impacts that explains the mechanism or process by which variables interact. Moreover, the role of management and quality sciences is not limited to identifying activities that result in the achievement of objectives. This also involves describing, explaining, and predicting successive states (Sudoł, 2014, p. 18). Hence, with the introduction of mediators into the model, I will attempt to explain the mechanisms underlying the relationship between absorptive capacity reinforced by orientation on organisational learning and specific types of innovation.

Within the scope of these considerations, what deserves special attention is knowledge sharing. Under conditions in which knowledge is identified as the key source of competitive advantage, knowledge sharing becomes a priority (Grant, 1996). Knowledge sharing allows for maximising business capabilities (McEvily, Das, \& McCabe, 2000). It is an essential element 
in the functioning of any organisation, since it increases the organisation's innovation efficiency (Han, Jo, \& Kangi, 2016). Knowledge sharing will be considered a mediator of relationship between absorptive capacity and innovation capacity if the following relationships are confirmed, namely the relationship between absorptive capacity and knowledge sharing and between knowledge sharing and innovation capacity.

The results of previous studies indicate the presence of statistically significant relationships between absorptive capacity and knowledge sharing (Arnold et al., 2010), but also between knowledge sharing and innovation capability (Yeçil, Büyükbeşe, \& Koska, 2013; Le \& Lei, 2019). Furthermore, there exists empirical evidence concerning the impact of knowledge sharing on product innovation (Maes \& Sels, 2014; Lyytinen, Yoo, \& Boland, 2016; Markovic $\&$ Bagherzadeh, 2018). Researchers argue that there is a relationship between knowledge sharing and process innovation (Shu et al., 2012; Prodan \& Murovec, 2009). Moreover, scholars report the existence of impacts of knowledge sharing on management innovation (Buenechea, Kianto, \& Sáenz, 2018). Therefore, we may assume that knowledge sharing is a mediator in the relationship between absorptive capacity and innovation capability. The mediation occurs if the effect of the independent variable on the dependent variable is transmitted through a third variable (Cohen et al., 2003, p. 158-161), known as the mediating variable (or mediator). In light of the above, I propose the following hypotheses:

H3a: Knowledge sharing is a mediator in the relationship between absorptive capacity and product innovation.

H3b: Knowledge sharing is a mediator in the relationship between absorptive capacity and product innovation.

H3c: Knowledge sharing is a mediator in the relationship between absorptive capacity and managerial innovation.

Knowledge sharing involves the dissemination of knowledge within a group of employees or the transfer of this resource category between certain individuals, teams, or occupational groups (Probst, Raub, \& Romhardt, 2012, p. 146). Probst, Raub, and Romhardt suggest that knowledge sharing can occur at the individual, team, or organisation level. However, they indicate that knowledge is a good that can often be transmitted only through direct exchange between specific people. Davenport and Prusak (1998) also suggest that knowledge is personal. They believe that an organisation can effectively manage its knowledge resources if employees are willing to cooperate. For this reason, our considerations primarily focus on knowledge sharing at the individual level. For individual employees, knowledge sharing means conversations with colleagues that enable them to do something better, faster, or more effectively. By knowledge sharing with others, they also learn how to use their own knowledge in other areas (Cohen et al., 1990). Therefore, individual employee knowledge sharing allows for mutual learning, which may lead to improved results within the organisation (Reinholt \& Foss, 2011; Stelmaszczyk, 2016).

Knowledge sharing is a process by which employees mutually exchange knowledge and create new knowledge (Ozer \& Vogel, 2015). It consists of knowledge donating and knowledge collecting. Knowledge donating is the willingness of employees to actively communicate with colleagues and share their knowledge. By contrast, knowledge collecting involves active consultations with colleagues in order to learn from them. In other words, knowledge donating means acquiring it from a database or some other source, and then 
transferring it to the addressee, while knowledge collecting involves the acceptance of acquired knowledge and the assimilation and use of said knowledge (Cavaliere \& Lombardi, 2015). Knowledge donating consists of sharing one's own intellectual capital with others, which from an economic viewpoint means more costs than benefits. On the other hand, knowledge collecting allows one to benefit from the intellectual capital of others. In this situation, the benefits often outweigh the costs.

For the purposes of the present study, I developed a research model, which forms the basis for the presentation of allocation of research hypotheses that require empirical validation (Figure 1).

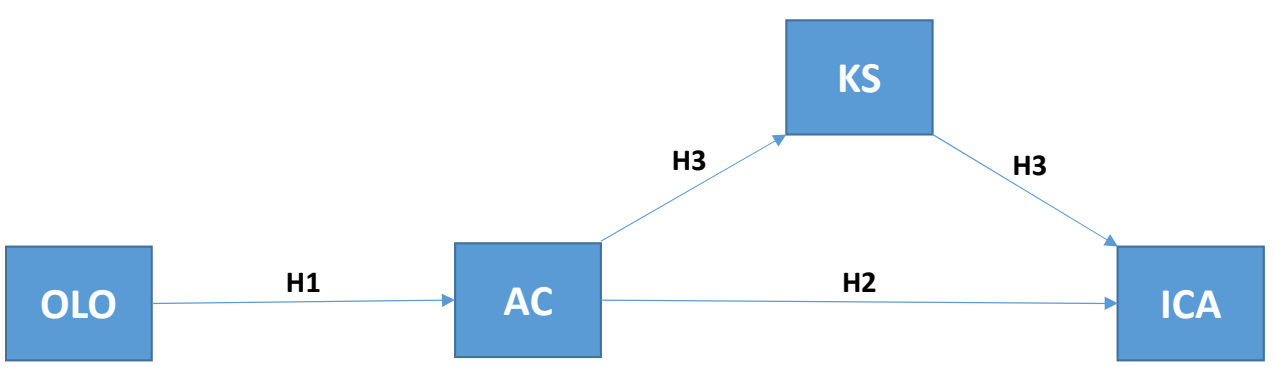

Figure 1. Proposed theoretical model

Source: own elaboration.

\section{MATERIAL AND METHODS}

The object of research is the enterprise's registered office in a town in East-Central Poland. This enterprise specialises in the production of high-quality insulating glass and special glass. It is one of the leading manufacturers in this sector in Poland. The enterprise offers a range of products: heat protection panes, laminated panes, soundproof panes, solar panels, decorative panes, and so-called special glass like hardened glass, half-hardened glass, and enamelled glass. This enterprise has a modern machine park supported by cutting-edge technological solutions. Over the period covered by the study, the enterprise had 427 persons in its employment.

In attempting to compete effectively with other enterprises in the market, Effect Glass S.A. wants to raise its ability to create and implement innovations. Effect Glass constantly seeks for ways to introduce new or significantly improved products, production methods, regulations, and management methods. Thus, the enterprise seeks significant and lasting cause-effect relationships between knowledge and the development of innovation. It is for this reason that I selected Effect Glass for the study.

This study was conducted between January and March 2017. The survey questionnaire was used to measure the relationship between absorptive capacity, organisational learning orientation and innovation capability. The study uses a seven-item Likert scale that ranges from (1) "strongly disagree" to "strongly agree" (7). The survey questionnaire was addressed to all employees of the enterprise, i.e. to 427 persons. Responses with missing data or contradictory or incomprehensible answers were eliminated. A total of 239 valid questionnaires were obtained (demographic characteristics of the sample are shown in Table 1). 
Table 1. Sample demographics

\begin{tabular}{|c|c|c|c|}
\hline \multicolumn{2}{|c|}{ Category } & Frequency & $\%$ \\
\hline \multirow{3}{*}{ Sex } & Female & 84 & 35.1 \\
\cline { 2 - 4 } & Male & 155 & 64.9 \\
\hline \multirow{3}{*}{ Age } & Under 30 & 62 & 25.8 \\
\cline { 2 - 4 } & $30-39$ & 108 & 45.0 \\
\cline { 2 - 4 } & $40-49$ & 61 & 25.4 \\
\hline \multirow{3}{*}{$\begin{array}{c}\text { Employment pe- } \\
\text { riod }\end{array}$} & $50-59$ & 9 & 3.8 \\
\cline { 2 - 4 } & 1 year or less & 99 & 28.8 \\
\cline { 2 - 4 } & $2-3$ years & 63 & 37.5 \\
\cline { 2 - 4 } & 4-5 years & 18 & 26.3 \\
\hline
\end{tabular}

Source: own study.

\section{Dependent Variable}

Innovation capability is the ability to create and implement new ideas resulting in innovation whose spread brings benefit to the enterprise (Jain, 2013). In this study, innovation capability is based on the scale developed by Tsai et al. (2001b), which measures product innovations (six items), process innovations (five items), and managerial innovations (seven items). The value of Cronbach's $\alpha$ for product innovations is 0.82 , for process innovations it is 0.79 and for managerial innovations it is 0.82 .

\section{Independent variables}

Absorptive capacity is the ability of business to acquire, assimilate, transform, and exploit external knowledge (Zahra et al., 2002). Absorptive capacity was measured using a ten-item scale developed by Pavlou and Sava (2006). Cronbach's value of $\alpha$ for this variable is 0.91.

Organisational learning orientation involves activities undertaken by the entire organisation to create and use knowledge in order to increase competitive advantage (Calantone et al., 2002, p. 516). This study adopted a scale proposed by Sinkula et al. (1997) and Baker and Sinkula (1999). The scale has three dimensions: commitment to learning (four items), shared vision (four items), and open-mindedness (four items). The values of Cronbach's $\alpha$ for each of the coefficients are $0.84,0.82$ and 0.77 , respectively.

\section{Mediating Variable}

Knowledge sharing is a process by which employees mutually exchange knowledge and create new knowledge (Ozer et al., 2015). Knowledge sharing is measured using a 10-item scale developed by Van den Hooff and Van Weenen (2004). The scale consists of two dimensions: knowledge donating (five items) and knowledge collecting (five items). The values of Cronbach's $\alpha$ for knowledge donating and knowledge collecting are 0.90 and 0.92 , respectively (see Appendix: List of measurement items).

This survey investigated the issue of causality. I prepared a theoretical model to explain the studied phenomenon and its empirical verification using Structural Equation Modelling (SEM). SEM allows for a multidimensional and multivariate analysis of empirical data. SEM has the unique ability to simultaneously examine multiple variables, especially 
in the case when the dependent variable becomes an independent variable in subsequent relationships within the same analysis (Shook et al., 2004).

In order to verify the research hypotheses, I conducted a number of statistical analyses. Basic descriptive statistics, the Kolmogorov-Smirnov test, the Shapiro-Wilk tests, and the analysis of frequency and Cronbach's $\alpha$ reliability coefficients were all calculated with Orange Canvas software. I used EQS software to analyse structural equations.

\section{RESULTS}

The analysis initially measured the accuracy of the scales used, using Cronbach's $\alpha$. The results of the analysis indicate that all of the scales used to build the path-based model have a reliability greater than 0.7 . This proves to be a highly satisfactory measurement accuracy of the scales, which results in a very small measurement error of the traits studied. In addition, basic descriptive statistics were calculated, along with the Kolmogorov-Smirnov (K-S) and Shapiro-Wilk (S-W) tests. By using the K-S and S-W tests, analyses were conducted to verify the similarities in the distribution of all measured variables in relation to the theoretical normal distribution. Test results indicate that distributions of variables in this study have a significantly different shape than the theoretical normal distribution. Despite this, a visual assessment of histograms shows that distributions of variables are symmetrical and more similar to a normal distribution than to any other known distribution. Cronbach's $\alpha$ coefficients, basic descriptive statistics and K-S and S-W test results are presented in table 2.

Table 2. Descriptive statistics, Cronbach's alpha reliability coefficient, and measured variables normality distribution tests

\begin{tabular}{|l|l|c|c|c|c|c|c|c|c|c|}
\hline & Statistics & AC & OLO1 & OLO2 & OLO3 & ICA1 & ICA2 & ICA3 & KSd & KSC \\
\hline \multirow{2}{*}{$\begin{array}{l}\text { Reliability } \\
\text { statistics }\end{array}$} & Cronbach's alpha & 0.91 & 0.84 & 0.82 & 0.77 & 0.82 & 0.79 & 0.82 & 0.90 & 0.92 \\
\hline \multirow{5}{*}{$\begin{array}{l}\text { Descriptive } \\
\text { statistics }\end{array}$} & Number of positions & 10.0 & 4.00 & 4.00 & 4.00 & 6.00 & 5.00 & 7.00 & 5.00 & 5.00 \\
\cline { 2 - 10 } & Average & 4.61 & 4.32 & 4.21 & 4.30 & 4.63 & 4.65 & 4.38 & 5.02 & 5.09 \\
\cline { 2 - 9 } & Sedian & 4.70 & 4.50 & 4.25 & 4.25 & 4.50 & 4.60 & 4.43 & 5.00 & 5.20 \\
\cline { 2 - 9 } & Standard deviation & 0.93 & 1.02 & 1.02 & 1.05 & 0.87 & 0.92 & 0.87 & 1.10 & 1.09 \\
\cline { 2 - 9 } & Kurtosis & -0.30 & -0.45 & 0.05 & 0.04 & 0.17 & -0.07 & -0.36 & -0.42 & -0.71 \\
\cline { 2 - 9 } & Minimum & 0.52 & 0.51 & 0.23 & -0.50 & -0.63 & 0.69 & 0.92 & 0.37 & 1.00 \\
\cline { 2 - 9 } & Maximum & 1.00 & 1.00 & 1.00 & 2.00 & 2.83 & 1.00 & 1.00 & 1.00 & 1.00 \\
\hline \multirow{2}{*}{$\begin{array}{l}\text { Kolmogorov- } \\
\text { Smirnov }\end{array}$} & K-S Statistics & 6.70 & 6.75 & 7.00 & 7.00 & 6.83 & 7.00 & 6.29 & 7.00 & 7.00 \\
\cline { 2 - 9 } & Validity & 0.06 & 0.09 & 0.07 & 0.06 & 0.07 & 0.07 & 0.10 & 0.09 & 0.12 \\
\hline \multirow{2}{*}{ Shapiro-Wilk } & S-W Statistics & 0.039 & 0.000 & 0.005 & 0.029 & 0.005 & 0.003 & 0.000 & 0.000 & 0.000 \\
\cline { 2 - 9 } & Validity & 0.990 & 0.980 & 0.990 & 0.990 & 0.980 & 0.990 & 0.980 & 0.980 & 0.960 \\
\hline
\end{tabular}

Source: own study.

\section{Structural Equation Modelling (SEM)}

In order to verify the theoretical model, I conducted an analysis of structural equations using the asymptotically distribution free (ADF) method. The results of the analysis show that the model explaining the influences and relationships between variables fits the empirical data very well. Measurements of the model fit of the data are satisfactory [CMIN/DF=3.64, $G F I=0.95, C F I=0.87, R M S E A=0.11$ (ci=0.08-0.14), $A I C=114.52, B I C=117.13$. 
The analysis of influence coefficients of the model demonstrated a statistically significant effect of organisational learning orientation (OLO) on the absorptive capacity (AC) of the surveyed enterprise. Absorptive capacity is most strongly affected by commitment to learning (OLO1), less affected by open-mindedness (OLO3), and least affected by shared vision (OLO2). It is demonstrated by the values of standardised coefficients of 8 regression, which are 0.39 , 0.37 , and 0.19 , respectively. However, the value of the $R^{2}$ determination coefficient of 0.67 indicates that the variance in terms of OLO1, OLO2, and OLO3 explains $67 \%$ of the variation in the AC measurement (Table 3). Obviously, these dependencies occur with the assumption that the individual dimensions of organisational learning orientation are significantly statistically correlated (correlation coefficient values range from 0.55 to 0.65 : Table 4).

Table 3. Estimation results of the path-based model

\begin{tabular}{|c|c|c|c|c|c|c|c|}
\hline $\mathbf{R}^{2}$ & Variable & $\begin{array}{l}\text { Direction } \\
\text { of impact }\end{array}$ & Variable & B & S.E. & $\beta$ & C.R. \\
\hline \multirow{3}{*}{0.67} & $\mathrm{AC}$ & \multirow{14}{*}{$<$} & OLO1 & 0.37 & 0.05 & 0.39 & $8.20 * * *$ \\
\hline & $A C$ & & OLO2 & 0.17 & 0.05 & 0.19 & $3.20 * *$ \\
\hline & $A C$ & & OLO3 & 0.34 & 0.06 & 0.37 & $6.03 * * *$ \\
\hline 0.16 & KSd & & $A C$ & 0.45 & 0.07 & 0.39 & $6.80 * * *$ \\
\hline 0.17 & KSc & & $A C$ & 0.46 & 0.07 & 0.41 & $6.52 * * *$ \\
\hline \multirow{3}{*}{0.47} & ICA1 & & KSc & 0.09 & 0.06 & 0.11 & 1.70 \\
\hline & ICA1 & & $A C$ & 0.49 & 0.06 & 0.53 & $8.20 * * *$ \\
\hline & ICA1 & & KSd & 0.15 & 0.05 & 0.18 & $2.73 * *$ \\
\hline \multirow{3}{*}{0.44} & ICA2 & & KSc & 0.35 & 0.05 & 0.39 & $7.42^{* * *}$ \\
\hline & ICA2 & & $A C$ & 0.37 & 0.06 & 0.37 & $5.73 * * *$ \\
\hline & ICA2 & & KSd & 0.04 & 0.05 & 0.05 & 0.77 \\
\hline \multirow{3}{*}{0.31} & ICA3 & & KSc & 0.23 & 0.05 & 0.29 & $4.45^{* * *}$ \\
\hline & ICA3 & & $A C$ & 0.27 & 0.05 & 0.31 & $5.35^{* * *}$ \\
\hline & ICA3 & & KSd & 0.06 & 0.05 & 0.07 & 1.16 \\
\hline
\end{tabular}

$\mathrm{p}<0.001^{* * *}, \mathrm{p}<0.01^{* *}, \mathrm{p}<0.05^{*}$

Source: own study.

Table 4. Relationships between variables in the path-based model

\begin{tabular}{|c|c|c|c|}
\hline \multicolumn{2}{|c|}{ Relationship between variables } & $\mathbf{r}$ & C.R. \\
\hline OLO2 & OLO3 & 0.65 & $9.53^{* * *}$ \\
\hline OLO1 & OLO3 & 0.55 & $7.71^{* * *}$ \\
\hline OLO1 & OLO2 & 0.61 & $9.45^{* * *}$ \\
\hline KSd & KSC & 0.69 & $8.54^{* * *}$ \\
\hline ICA1 & ICA3 & 0.42 & $6.64^{* * *}$ \\
\hline ICA2 & ICA3 & 0.42 & $5.57^{* * *}$ \\
\hline ICA1 & ICA2 & 0.44 & $5.18^{* * *}$ \\
\hline
\end{tabular}

$\mathrm{p}<0.001^{* * *}, \mathrm{p}<0.01^{* *}, \mathrm{p}<0.05^{*}$

Source: own study.

Next, I observed that there is a statistically significant influence of AC on knowledge donating (KSd) and knowledge collecting (KSc). Indicative of this are the values of the standardised coefficients of $B$ regression that are 0.39 and 0.41 , respectively; assuming that both dimensions of knowledge sharing are correlated by an important relationship, 
in which $r$ equals 0.69 . Moreover, the value of the coefficient of $R^{2}$ determination for KSd and $\mathrm{KSC}$ is 0.17 and 0.16 , respectively. This means that the variability in AC explains $17 \%$ of the variation in $\mathrm{KSd}$ and $16 \%$ of the variation in KSc.

The results of subsequent analyses show the strongest and most statistically significant effect of $A C$ on the level of ICA1 $(B=0.53)$. AC has a lesser effect on ICA2 $(B=0.37)$ and the weakest effect on ICA3 $(B=0.31)$. Obviously, these dependencies occur with the assumption that the individual dimensions of organisational learning orientation are correlated via a statistically significant relationship (correlation coefficient values range from 0.42 to 0.44 ).

In the next stage of the analysis, I examined the impact of KSd and KSc on business innovation capability (ICA). It turns out that KSd significantly affects only product innovations (ICA1; $6=0.18$ ). In the case of process innovations (ICA2) and managerial innovations (ICA3), I observed no effect. Meanwhile, KSc has the strongest effect on ICA2 and a lesser effect on ICA3. The values of the standardised coefficients of $B$ regression are 0.39 and 0.29 , respectively; assuming that the individual dimensions of innovation capability are statistically related (correlation coefficient values range from 0.42 to 0.44 ). Therefore, the model explains $47 \%$ of the variation in ICA $1,44 \%$ of the variation in ICA2, and $31 \%$ of the variation in ICA3. The results of testing the hypothesised structural equation model are shown in Figure 2.

\section{The Analysis of Mediation Results}

In the analysis of the path-based model, mediating effects were obtained. The mediating effect of knowledge sharing (KSd and KSc) was revealed by the influence of AC on individual dimensions of innovation capability (ICA1, ICA2, ICA3). Here, we are dealing with a statistically significant but partial influence of dimensions of knowledge sharing on the relationship between AC and ICA1 ( $B=0.11 ; p<0.001), A C$ and ICA2 $(B=0.19 p<0.01)$, and AC and ICA3 $(B=0.15, p<0.01)$. The presence of KSd and KSc dimensions statistically significantly weakens the influence of AC on ICA1, ICA2, and ICA3. Yet it does not reduce it enough to cause direct effects of the influence of AC on ICA1, ICA2, and ICA3 to be statistically insignificant. This is shown by the significance of the direct effects of AC on ICA1 $(B=0.53 ; p<0.001)$, on ICA2 $(B=37 ; p<0.001)$, and on ICA3 $(B=0.31 ; p<0.01)$. Therefore, AC significantly affects ICA 1 , ICA2, and ICA3, while the dimensions of knowledge sharing (KSd and KSC) statistically significantly mediate this effect. The correlation between AC and ICA1, ICA2 and ICA3 occurs partly due to the presence of KSd and KSc within the set of variables (Table 5).

Table 5. The mediating effect of knowledge sharing in the relationship between knowledge collecting and innovation capability

\begin{tabular}{|c|c|c|c|c|}
\hline \multirow{2}{*}{$\begin{array}{c}\text { Mediating } \\
\text { variables }\end{array}$} & Direct effect & Indirect effect & \multirow{2}{*}{ Type of mediation } & Dependent variables \\
\cline { 2 - 4 } & $\mathbf{A C}$ & $\mathbf{A C}$ & & \\
\hline \multirow{3}{*}{$\mathrm{KSd}, \mathrm{KSC}$} & $0.53^{* * *}$ & $0.11^{* *}$ & Partial mediation & ICA1 \\
\cline { 2 - 5 } & $0.31^{* * *}$ & $0.15^{* *}$ & Partial mediation & ICA3 \\
\cline { 2 - 5 } & $0.37^{* * *}$ & $0.19^{* *}$ & Partial mediation & ICA2 \\
\hline
\end{tabular}

Source: own study.

Summing up, we conclude that the mathematical structure of the model reflects the cause-and-effect influence of variables and dependencies between the variables. The influence of independent variables on dependent variables is very high. This is demonstrated 


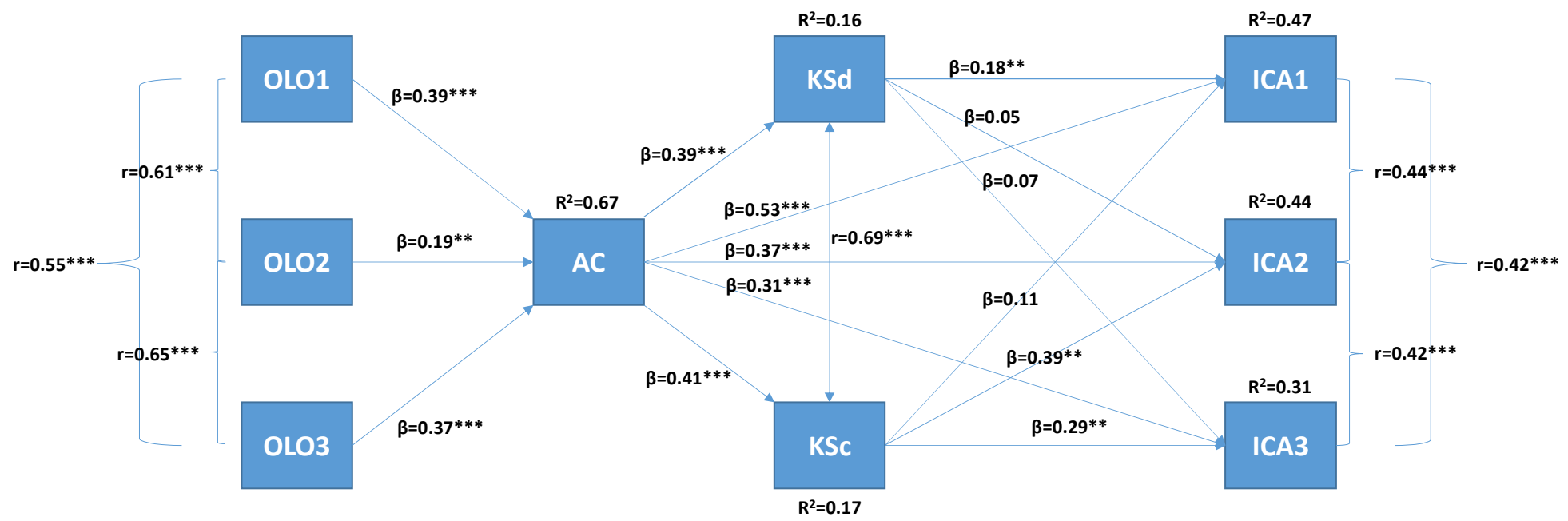

Figure 2. Results of structural equation modelling Source: own elaboration. 
by high values of the $R^{2}$ determination coefficients and the standardised coefficients of $B$ regression. Table 6 presents the results of the hypotheses tested in this study.

Table 6. Summary of Hypotheses Testing

\begin{tabular}{|l|c|}
\hline \multicolumn{1}{|c|}{ Hypotheses } & Result \\
\hline $\begin{array}{l}\text { H1a: there is a positive relationship between commitment to learning and } \\
\text { absorptive capacity }\end{array}$ & Supported \\
\hline $\begin{array}{l}\text { H1b: there is a positive relationship between shared vision and absorptive } \\
\text { capacity }\end{array}$ & Supported \\
\hline $\begin{array}{l}\text { H1c: there is a positive relationship between open-mindedness and ab- } \\
\text { sorptive capacity }\end{array}$ & Supported \\
\hline $\begin{array}{l}\text { H2a: there is a positive relationship between absorptive capacity and } \\
\text { product innovation }\end{array}$ & Supported \\
\hline $\begin{array}{l}\text { H2b: there is a positive relationship between absorptive capacity and pro- } \\
\text { cess innovation }\end{array}$ & Supported \\
\hline $\begin{array}{l}\text { H2c: there is a positive relationship between absorptive capacity and man- } \\
\text { agerial innovation }\end{array}$ & Supported \\
\hline $\begin{array}{l}\text { H3a: knowledge sharing is a mediator in the relationship between absorp- } \\
\text { tive capacity and product innovation }\end{array}$ & Supported \\
\hline $\begin{array}{l}\text { H3b: knowledge sharing is a mediator in the relationship between absorp- } \\
\text { tive capacity and process innovation }\end{array}$ & Supported \\
\hline $\begin{array}{l}\text { H3c: knowledge sharing is a mediator in the relationship between absorp- } \\
\text { tive capacity and managerial innovation }\end{array}$ & Supported \\
\hline
\end{tabular}

Source: own study.

\section{DISCUSSION AND CONCLUSION}

\section{Contribution to Theory}

The purpose of this study was to identify the cause-and-effect relationships that occur among organisational learning orientation, absorptive capacity, and business innovation capability. The results prove to be interesting, while understanding them may have significant theoretical and practical implications.

There are three issues that this study contributes to the development of the literature on strategic management. First, this study expands our understanding of the effect of organisational learning orientation on absorptive capacity. The results of this analysis indicate that organisational learning orientation strongly impacts the acquisition, assimilation, and exploitation of external knowledge. Previously, little was known about the antecedents of absorptive capacity (Volberda et al., 2010). The present study fills this gap, as it confirms the existence of relationships between organisational learning orientation and absorptive capacity. This means that a strong organisational learning orientation increases absorptive capacity. The results show that an organisation's commitment to learning has the strongest effect on absorptive capacity. Likewise, open-mindedness allows for acquiring useful external knowledge and using it in practice. The weakest factor that is antecedent to absorptive capacity is shared vision. However, bearing in mind the fact that this dimension orientates the learning process, it should not be ignored. In addition, it is strongly and positively correlated with the organisation's other learning orientation dimensions. This highlights the important 
role of this variable in the research model. In conclusion, up to $67 \%$ of the variation in absorptive capacity is explained by the influence of organisational learning orientation. Therefore, the empirical analysis results confirm the role of organisational learning orientation as the key factor antecedent to absorptive capacity.

The second theoretical implication of this study is the confirmation of the presence of a statistically significant and positive relationship between absorptive capacity and innovation capability. The obtained results confirm the results of earlier studies conducted by Cohen et al. (1990), Tsai (2001a), Zahra et al. (2002), and Tortoriello (2015). Moreover, Moilanen et al. (2014) note the existence of a positive but very weak relationship between absorptive capacity and product innovations. Zhang et al. observe a stronger direct impact of one variable on the other (2018). However, the impact of innovative ability on product innovation in our case is also positive but definitely stronger. It is the orientation on organisational learning included in the model that triggered a stronger relationship between absorptive capacity and product innovation. In turn, Najafi-Tavani et al. (2018) state that the impact of collaborative innovation networks on process innovation is only relevant when absorptive capacity appears. They studied indirect effects collaborative innovation networks on process innovation and absorptive capacity on process innovation. However, their study allows for a conclusion that there is a significant relationship between absorptive capacity and process innovation. Similarly, Aliasghar et al. (2019) indicate a moderately strong relationship between potential absorptive capacity and process innovations. Therefore, our study confirms the occurrence of this relationship: it is clear but a little weaker. In turn, the impact of absorptive capacity on management innovations has so far been rarely analysed. Peeters et al. (2014) propose a conceptual research model in which they suggest that absorptive capacity routines can affect the effectiveness of innovation in management innovation management. By contrast, Ali et al. (2016) empirically demonstrate that any increase in the individual dimensions of the absorptive capacity results in an increase in the management innovation. The current study also demonstrates a positive relationship between these variables, with the absorptive capacity being treated as a one-dimensional variable.

The added value of the present study lies in the filling of the research gap noted by Lane et al. (2006), Volberda et al. (2010), and Tortoriello (2015). That is, they all argue that the mechanisms that transform external knowledge into innovations have yet been neither sufficiently recognised nor examined. Therefore, through the inclusion of organisational learning orientation, this study enables a better understanding of the impact of absorptive capacity on the innovation capability. Absorptive capacity needs organisational learning orientation in order to create innovation capability. Absorptive capacity generated by organisational learning orientation has the strongest direct impact on product innovations; it has a lesser effect on process innovations and the weakest effect on managerial innovations. Research shows that a stronger organisational learning orientation increases absorptive capacity. In turn, new knowledge acquired and used thanks to absorptive capacity enhances innovation capability; i.e. an increase in product, process, and managerial innovations. The main conclusion of the analysis is the following: the relationship of organisational learning orientation with absorptive capacity can lead to easier transformations of assimilated external knowledge into innovation.

The third theoretical implication concerns the indirect dependencies between absorptive capacity and innovation capability. It turns out that knowledge sharing - in the form 
of knowledge donating and knowledge collecting - significantly mediates in the relationship between these variables. Therefore, what enabled the identification of the mediation is the empirical evidence for the existence of relationships between absorptive capacity and knowledge sharing (Arnold et al., 2010), knowledge sharing and product (Maes et al., 2014; Lyytinen et al., 2016; Markovic et al., 2018), but also process innovation (Shu et al., 2012; Prodan et al., 2009) and managerial innovation (Buenechea et al., 2018). The identification of mediation demonstrates that absorptive capacity impacts each of the mentioned types of innovations through knowledge sharing in the studied enterprise. Thus, an enterprise can improve its innovation capacity both by increasing its absorptive capacity and by improving knowledge sharing. Of course, this is only a partial mediation, since we know that there exist other mediators beside knowledge sharing, which were not included in the study. However, knowledge sharing most strongly affects the relationship between the absorptive capacity and product innovation. This is clearly proven by the strength of the impact of absorptive capacity on product innovation, which significantly decreases after the introduction of a mediator into the model. Moreover, it depends on the intensity of the process of knowledge sharing. Thus, knowledge sharing constitutes an important factor, while the external knowledge acquired is used to develop and implement new products, but also to improve the quality of existing products.

\section{Contribution to Practice}

In practice, this study has three main implications. Firstly, it provides top management with ideas on the development of innovation capability. New knowledge obtained from external sources and applied in practice most strongly affects product innovations. Therefore, the expansion of absorptive capacity should be seen as a key factor affecting the development and implementation of new products, but also as the improvement in the quality of existing products. Thus, in the case of product innovation, managers should pay particular attention to the quality and kind of knowledge acquired from external sources. They should also make every effort to ensure that the knowledge acquired is assimilated and put to practical use by the organisation. On the other hand, absorptive capacity is one of many factors that affect process and managerial innovations. This means that only a fraction of the data complies with the implied dependency. The trend is visible, but some deviations may occur.

Secondly, if employees are more willing to share their knowledge with others in the enterprise, it will facilitate the transformation of acquired and assimilated knowledge into innovation capability. The strongest relationship of this type occurs between absorptive capacity and product innovation. Therefore, managers can engage in developing mechanisms for knowledge sharing and encouraging employees to directly exchange knowledge, thus strengthening the impact of absorptive capacity on the capability to create product innovations. In other words, they can allow for a maximisation of capabilities for business product innovation. The results of my analyses show that the process of knowledge sharing within the enterprise can become an important mechanism to facilitate the transformation of external knowledge into product innovations.

Thirdly, in order for an enterprise to be able to benefit from its absorptive capacity, it must be committed to learning and feel an obligation to be open-minded towards new information and new methods of action. The enterprise should also be engaged in a common interpretation of obtained information and in reaching a general consensus as to its meaning. Reagans and McEvily (2003) show that organisation participants can absorb 
knowledge with more ease if there is already some common - basic and specialist knowledge made available to them. Therefore, managers should support learning at all levels: individual, team, and organisational. They should develop new skills and encourage rejecting outdated and impractical knowledge. By strengthening organisational learning orientation, the enterprise will be able to build its absorptive capacity.

\section{Limitations and Future Research}

As with all research, any conclusions based on the results obtained should be interpreted with certain limitations in mind. Firstly, in the cause-and-effect research model, I consider linear relationships between variables. The results confirm the existence of a positive linear relationship, e.g. between the three dimensions of organisational learning orientation and absorptive capacity. A reasonable explanation of this fact is that the enterprise must continuously strive to strengthen the organisational learning orientation so that its absorptive capacity can grow. This study highlights the benefits of organisational learning orientation. However, it does not tackle costs. A stronger focus on organisational learning orientation may be likely accompanied by a decrease in absorptive capacity. A similar correlation was observed concerning the impact of absorptive capacity on inter-organisational learning (Schildt, Keil, \& Maula, 2012). Therefore, a pattern based on linear relationship can only occur up to a certain level of organisational learning orientation. Beyond that, a decrease in absorptive capacity may be experienced. In light of this fact, future research should examine the hypothesis about the existence of an inverted U-shaped relationship between organisational learning orientation and absorptive capacity.

The second limitation relates to the sample selection, as it was limited to one enterprise. It may be interesting to examine the proposed research model in other enterprises that also specialise in the production of insulating glass. In the future, researchers may also attempt to advance our understanding of the relationship between organisational learning orientation, absorptive capacity, and innovation capability in other business sectors.

\section{REFERENCES}

Ali M., Kan K.A.S., \& Sarstedt M. (2016). Direct and Configurational Paths of Absorptive Capacity and Organizational Innovation to Successful Organizational Performance. Journal of Business Research, 69(11), 5317-5323. https://doi.org/10.1016/j.jbusres.2016.04.131

Aliasghar, O., Rose, E.L., \& Chetty S. (2019). Where to Search for Process Innovations? The Mediating Role of Absorptive Capacity and Its Impact on Process Innovation. Industrial Marketing Management, 82. https://doi.org/10.1016/j.indmarman.2019.01.014

Argote, L. (2013). Organizational Learning: Creating, Retaining and Transferring Knowledge. New York: Springer.

Arnold, V., Benford, T., Hampton, C., \& Sutton, S.G. (2010). Competing Pressures of Risk and Absorptive Capacity Potential on Commitment and Information Sharing in Global Supply Chains. European Journal of Information Systems, 19(2), 134-152. https://doi.org/10.1057/ejis.2009.49

Baker, W.E., \& Sinkula J.M. (1999). The Synergistic Effect of Market Orientation and Learning Orientation on Organizational Performance. Journal of the Academy of Marketing Science, 27(4), 411427. https://doi.org/10.1177/0092070399274002

Baum, C.F., Lööf, H., \& Nabavi, P. (2019). Innovation strategies, external knowledge and productivity growth. Industry \& Innovation, 26(3), 348-367. https://doi.org/10.1080/13662716.2018.1499502 
Buenechea, E.M., Kianto, A., \& Sáenz, J. (2018). Intellectual Capital Drivers of Product and Managerial Innovation In High-Tech and Low-Tech Firms. R\&D Management, 48(3), 290-307. https://doi.org/10.1111/radm.12271

Calantone, R.J., Cavusgil, S.T., \& Zhao, Y. (2002). Learning Orientation, Firm Innovation Capability, and Firm Performance. Industrial Marketing Management, 31(6), 515-524. https://doi.org/10.1016/S0019-8501(01)00203-6

Cavaliere, V., \& Lombardi, S. (2015). Exploring Different Cultural Configurations: How Do They Affect Subsidiaries' Knowledge Sharing Behaviors? Journal of Knowledge Management, 19(2), 141163. https://doi.org/10.1108/JKM-04-2014-0167

Cockburn, I.M., \& Henderson, R.M. (1998). Absorptive Capacity, Coauthoring Bahavior, and the Organization of Research in Drug Discovery. Journal of Industrial Economics, 46(2), 157-182.

Cohen, J., Cohen, P., West, S.G., \& Aiken, L.S. (2003). Applied Multiple Regression. Correlation Analysis for the Behavioral Sciences. New York: Mahwah Lawrence Erlbaum.

Cohen, W.M., \& Levinthal, D.A. (1989). Innovation and Learning: The Two Faces of R\&D. Economic Journal, 99(397), 569-596. https://doi.org/10.2307/2233763

Cohen, W.M., \& Levinthal, D.A. (1990). Absorptive Capacity: A New Perspective on Learning and Innovation. Administrative Science Quarterly, 35(1), 128-152. https://doi.org/10.2307/2393553

Davenport, T., \& Prusak, L. (1998). Working Knowledge. Harvard Business School Press: Cambridge, MA.

Farkas, G. (2016). The Effects of Strategic Orientations and Perceived Environment on Firm Performance. Journal of Competitiveness, 8(1), 55-65. https://doi.org/10.7441/joc.2016.01.04

Feng, T., Zhao, G., \& Su, K. (2014). The Fit Between Environmental Management Systems and Organisational Learning Orientation. International Journal of Production Research, 52(10), 2901-2914. https://doi.org/10.1080/00207543.2013.857055

Fernhaber, S.A., \& Patel, P.C. (2012). How Do Young Firms Manage Product Portfolio Complexity? The Role of Absorptive Capacity and Ambidexterity. Strategic Management Journal, 33(13). https://doi.org/1516-1539, 10.1002/smj.1994

Fosfuri, A., \& Tribó, J.A. (2008). Exploring the Antecedents of Potential Absorptive Capacity and Its Impact on Innovation Performance. Omega, 36(2), 173-187. https://doi.org/10.1016/j.omega.2006.06.012

Godart, F.C., Maddux, W.W., Shipilov, A.V., \& Galinsky, A. (2015). Fashion with a Foreign Flair: Professional Experiences Abroad Facilitate the Creative Innovations of Organizations. Academy of Management Journal, 58(1). https://doi.org/195-220, 10.5465/amj.2012.0575

Grant, R.M. (1996). Toward a Knowledge Based Theory of the Firm. Strategic Management Journal, 17, 109-122. https://doi.org/10.1002/smj.4250171110

Grigoriou, K., \& Rothaermel, F.T. (2017). Organizing for Knowledge Generation: Internal Knowledge Networks and the Contingent Effect of External Knowledge Sourcing. Strategic Management Journal, 38(2), 395-414. https://doi.org/10.1002/smj.2489

Guinot, J., Chiva, R., \& Mallén, F. (2013). Organizational Trust and Performance: Is Organizational Learning Capability a Missing Link?. Journal of Management \& Organization, 19(5), 559-582. https://doi.org/10.1017/jmo.2014.3

Gutie'rrez, L.J.G., Bustinza, O.F., \& Molina, V.B. (2012). Six Sigma, Absorptive Capacity and Organisational Learning Orientation. International Journal of Production Research, 50(3), 661-675.

Han, J., Jo, G.S., \& Kang, J. (2016). Is High-Quality Knowledge Always Beneficial? Knowledge Overlap and Innovation Performance in Technological Mergers and Acquisitions. Journal of Management \& Organization, 24(2), 1-21. https://doi.org/10.1017/jmo.2016.35

Huang, F., Rice, J., \& Martin, N. (2015). Does Open Innovation Apply to China? Exploring the Contingent Role of External Knowledge Sources and Internal Absorptive Capacity in Chinese 
Large Firms and SMEs. Journal of Management \& Organization, 21(5), 594-613. https://doi.org/10.1017/jmo.2014.79

Jain, A. (2013). Learning by Doing and the Locus of Innovative Capability in Biotechnology Research. Organization Science, 24(6), 1683-1700. https://doi.org/10.1287/orsc.2013.0821

Jerez-Gómez, P., Céspedes-Lorente, J., \& Pérez-Valls, M. (2017). Do High-Performance Human Resource Practices Work? The Mediating Role of Organizational Learning Capability. Journal of Management \& Organization, 25(2), 1-22. https://doi.org/10.1017/jmo.2017.55

Kedia, B.L., \& Bhagat, R.S. (1988). Cultural Constraints on Transfer of Technology Across Nations: Implications for Research in International and Comparative Management. Academy of Management Review, 13(4), 559-571. https://doi.org/doi.org/10.5465/amr.1988.4307424

Kim, L. (1998). Crisis Construction and Organizational Learning: Capability Building in Catching-Up at Hyundai Motor. Organization Science, 9(4), 506-521. https://doi.org/10.1287/orsc.9.4.506

Krawczyk-Sokołowska, I., Pierścieniak, A., \& Caputa, W. (2019). The Innovation Potential of the Enterprise in the Context of the Economy and the Bussines Model. Review of Management Science. https://doi.org/10.1007/s11846-019-00374-z

Lane, P.J., Koka, B.R., \& Pathak, S. (2006). The Reification of Absorptive Capacity: A Critical Review and Rejuvenation of the Construct. Academy of Management Review, 31(4), 833-863. https://doi.org/10.5465/AMR.2006.22527456

Lane, P.J., Salk, J.E., \& Lyles, M.A. (2001). Absorptive Capacity, Learning, and Performance in International Joint Ventures. Strategic Management Journal, 22(12), 1139-1161. https://doi.org/10.1002/smj.206

Laursen, K., \& Salter, A.J. (2006). Open For Innovation: The Role of Openness in Explaining Innovative Performance Among UK Manufacturing Firms. Strategic Management Journal, 27(2), 131-150. https://doi.org/doi.org/10.1002/smj.507

Le, P.B., \& Lei, H. (2019). Determinants of innovation capability: the roles of transformational leadership, knowledge sharing and perceived organizational support. Journal of Knowledge Management, 23(3), 527-547. https://doi.org/10.1108/JKM-09-2018-0568.

Lenox, M., \& King, A. (2004). Prospects for Developing Absorptive Capacity Through Internal Information Provision. Strategic Management Journal, 25(4), 331-345. https://doi.org/10.1002/smj.379

Lewin, A.Y., Massini, S., \& Peeters, C. (2011). Microfoundations of Internal and External Absorptive Capacity Routines. Organization Science, 22(1), 81-98. https://doi.org/10.1287/orsc.1100.0525

Lichtenthaler, U. (2009). Absorptive Capacity, Environmental Turbulence and the Complementarity of Organizational Learning Processes. Academy of Management Journal, 52(4), 822-846. https://doi.org/10.5465/AMJ.2009.43670902

Lyytinen, K., Yoo, Y., \& Boland Jr., R.J. (2016). Digital Product Innovation Within Four Classes of Innovation Networks. Information Systems Journal, 26(1), 47-75. https://doi.org/10.1111/isj.12093

Maes, J., \& Sels, L. (2014). SMEs' Radical Product Innovation: The Role of Internally and Externally Oriented Knowledge Capabilities. Journal of Small Business Management, 52(1), 141-63. https://doi.org/10.1111/jsbm.12037

Mamun, A., Fazal, S.A., Mohiuddin, M., \& Su, Z. (2019). Strategic orientations, the mediating effect of absorptive capacity and innovation: a study among malaysian manufacturing SMEs. International Journal of Innovation Management, 23(2). https://doi.org/10.1142/S1363919619500166

Markovic, S., \& Bagherzadeh, M. (2018). How Does Breadth of External Stakeholder Co-Creation Influence Innovation Performance? Analyzing the Mediating Roles of Knowledge Sharing and Product Innovation. Journal of Business Research, 88, 173-186. https://doi.org//10.1016/j.jbusres.2018.03.028 
McEvily, S.K., Das, S., \& McCabe, K. (2000). Avoiding Competence Substitution Through Knowledge Sharing. Academy of Management Review, 25(2), 294-311. 10.5465/AMR.2000.3312917

Miles, M.P., \& Arnold, D.R. (1991). The Relationship Between Marketing Orientation and Entrepreneurial Orientation. Entrepreneurship Theory and Practice, 15(4), 49-65.

Moilanen, M., Østbye, S., \& Woll, K. (2014). Non-R\&D SMEs: External Knowledge, Absorptive Capacity and Product Innovation. Small Business Economics, 43(2), 447-462. https://doi.org/10.1007/s11187-014-9545-9

Müller-Stewens, J., Schlager, T., Häubl, G., \& Herrmann, A. (2017). Gamified Information Presentation and Consumer Adoption of Product Innovations. Journal of Marketing, 81(2), 8-24. https://doi.org/10.1509/jm.15.0396

Najafi-Tavani, S., Najafi-Tavani, Z., Naudé, P., Oghazi, P., \& Zeynaloo, E. (2018). How Collaborative Innovation Networks Affect New Product Performance: Product Innovation Capability, Process Innovation Capability, and Absorptive Capacity. Industrial Marketing Management, 73, 193205. https://doi.org/10.1016/j.indmarman.2018.02.009

Newey, L., \& Verreynne, M.L. (2011). Multilevel Absorptive Capacity and Interorganizational New Product Development: A Process Study. Journal of Management \& Organization, 17(1), 39-55. https://doi.org/10.1017/S183336720000170X

Nonaka, I. (1994). A Dynamic Theory of Organizational Knowledge Creation. Organization Science, 5(1), 14-37. https://doi.org/10.1287/orsc.5.1.14

OECD (2005). Oslo Manual-Guidelines for Collecting and Interpreting Innovation Data. Third Edition. Paris: Organization for Economic Co-operation and Development. https://doi.org/10.1787/19900414

Ozer, M., \& Vogel, D. (2015). Contextualized Relationship Between Knowledge Sharing and Performance in Software Development. Journal of Management Information Systems, 32(2), 134-161. https://doi.org/10.1080/07421222.2015.1063287

Patel, P.C., Kohtamäki, M., Parida, V., \& Wincent, J. (2015). Entrepreneurial Orientation-as-Experimentation and Firm Performance: The Enabling Role of Absorptive Capacity. Strategic Management Journal, 36(11), 1739-1749. https://doi.org/10.1002/smj.2310

Panayides, P.M. (2007). The Impact of Organizational Learning on Relationship Orientation, Logistics Service Effectiveness and Performance. Industrial Marketing Management, 36(1), 68-80. https://doi.org/10.1016/j.indmarman.2005.07.001

Peeters, C., Massini, S., \& Lewin, A.Y. (2014). Sources of Variation in the Efficiency of Adopting Management Innovation: The Role of Absorptive Capacity Routines, Managerial Attention and Organizational Legitimacy. Organization Studies, 35(9), 1343-1371. https://doi.org/10.1177/0170840614539311

Penner-Hahn, J.D., \& Shaver, M.J. (2005). Does International Research and Development Increase Patent Output? An Analysis of the Japanese Pharmaceutical Firms. Strategic Management Journal, 26(2), 121-140. https://doi.org/doi.org/10.1002/smj.436

Prodan, I., \& Murovec, N. (2009). Absorptive Capacity, Its Determinants, and Influence on Innovation Output: Cross-Cultural Validation of The Structural Model. Technovation, 29(12), 859-872. https://doi.org/10.1016/j.technovation.2009.05.010

Reagans, R., \& McEvily, B. (2003). Network Structure and Knowledge Transfer: The Effects of Cohesion and Range. Administrative Science Quarterly, 48(2), 240-267. https://doi.org/10.2307/3556658

Reinholt, M., \& Foss, N.J. (2011). Why a Central Network Position Isn't Enough: The Role of Motivation and Ability for Knowledge Sharing in Employee Networks. Academy of Management Journal, 54(6), 1277-1297. https://doi.org/10.5465/amj.2009.0007 
Rothaermel, F.T., \& Alexandre, M.T. (2009). Ambidexterity in Technology Sourcing: The Moderating Role of Absorptive Capacity. Organization Science, 20(4), 759-780. https://doi.org/10.1287/orsc.1080.0404

Probst, G., Raub, S., \& Romhardt, K. (2012). Wissen Managen: Wie Unternrhmen Ihre Wertvollste Ressource Optimal Nutzen (7. Aufgabe). Wiesbaden: Springer Gabler.

Samson, D., \& Gloet, M. (2014). Innovation Capability in Australian Manufacturing Organizations: an Exploratory Study. International Journal of Production Research, 52(21), 6448-6466. https://doi.org/10.1080/00207543.2013.869368

Samson, D. (1991). Manufacturing and Operations Strategy. Wiesbaden: Prentice Hall.

Schildt, H., Keil, T., \& Maula, M. (2012). The Temporal Effects of Relative and Firm-Level Absorptive Capacity on Interorganizational Learning. Strategic Management Journal, 33(10), 1154-1173. https://doi.org/10.1002/smj.1963

Shu, C., Page, A.L., Gao, S., \& Jiang, X. (2012). Managerial Ties and Firm Innovation: Is Knowledge Creation a Missing Link?. Journal of Product Innovation Management, 29(1), 125-143. https://doi.org/doi.org/10.1111/j.1540-5885.2011.00883

Shook, C.L., Ketchen, Jr, D.J., Hult, G.T.M., \& Kacmar, K.M. (2004). Research Notes and Commentaries an Assessment of the Use of Structural Eouation Modeling in Strategic Management Research. Strategic Management Journal, 25(4), 397-404.

Sinkula, J.M., Baker, W.E., \& Noordewier, T. (1997). A Framework for Market-Based Organizational Learning: Linking Values, Knowledge, and Behaviour. Journal of the Academy of Marketing Science, 25(4), 305-318.

Stelmaszczyk, M. (2016). Relationship Between Individual and Organizational Learning: Mediating Role of Team Learning. Journal of Economics and Management, 26(4), 1732-1947. https://doi.org/10.22367/jem.2016.26.06

Sudoł, S. (2014). Podstawowe Problemy Metodologiczne Nauk o Zarządzaniu. Organizacja i Kierowanie, 1(161), 11-36.

Subramaniam, M., Youndt, M.A. (2005). The Influence of Intellectual Capital on the Types of Innovative Capabilities. Academy of Management Journal, 48(3), 450-463. https://doi.org/10.5465/AMJ.2005.17407911

Tavani, S.N., Sharifi, H. \& Ismail, H.S. (2014). A Study of Contingency Relationships Between Supplier Involvement, Absorptive Capacity and Agile Product Innovation. International Journal of Operations \& Production Management, 34(1), 65-92. https://doi.org/10.1108/IJOPM-09-2011-0331

Tortoriello, M. (2015). The Social Underpinnings of Absorptive Capacity: The Moderating Effects of Structural Holes on Innovation Generation Based on External Knowledge. Strategic Management Journal, 36(4), 586-597. https://doi.org/10.1002/smj.2228

Tsai, W. (2001a). Knowledge Transfer in Intraorganizational Networks: Effects of Network Position and Absorptive Capacity on Business Unit Innovation and Performance. Academy of Management Journal, 44(5), 996-1004.

Tsai, C.T., Huang, K.L., \& Kao, C.F. (2001b). The Relationships Among Organizational Factors, Creativity of Organizational Members and Innovation Capability. Journal of Management, 18, 527-566.

Van den Hooff, B., \& Van Weenen, F.L. (2004). Committed to Share: Commitment and CMC Use as Antecedents of Knowledge Sharing. Knowledge and Process Management, 11(1), 13-24. https://doi.org/10.1002/kpm.187

Volberda, H.W., Foss, N.J., \& Lyles, M.A. (2010). Absorbing the Concept of Absorptive Capacity: How To Realize Its Potential in the Organization Field. Organization Science, 21(4), 931-951. https://doi.org/10.1287/orsc.1090.0503 
Vuori, T.O., \& Huy, Q.N. (2016). Distributed Attention and Shared Emotions in the Innovation Process: How Nokia Lost the Smartphone Battle. Administrative Science Quarterly, 61(1), 9-51. https://doi.org/10.1177/0001839215606951

Wales, W.J., Parida, V., \& Patel, P.C., (2013). Too Much of a Good Thing? Absorptive Capacity, Firm Performance, and the Moderating Role of Entrepreneurial Orientation. Strategic Management Journal, 34(5), 622-633. https://doi.org/10.1002/smj.2026

Wang, C.L. (2008). Entrepreneurial Orientation, Learning Orientation, and Firm Performance. Entrepreneurship Theory \& Practice, 32(4), 635-657. https://doi.org/10.1111/j.1540-6520.2008.00246.x

Wang, H.C., He, J., \& Mahoney, J.T. (2009). Firm-Specific Knowledge Resources and Competitive Advantage: The Roles of Economic - and Relationship-Based Employee Governance Mechanisms. Strategic Management Journal, 30(12), 1265-1285. https://doi.org/doi.org/10.1002/smj.787

Wang, X., \& Dass, M. (2017). Building Innovation Capability: The Role of Top Management Innovativeness and Relative-Exploration Orientation. Journal of Business Research, 76, 127-135. https://doi.org/10.1016/j.jbusres.2017.03.019

Yeçil, S., Büyükbeşe, T., \& Koska, A. (2013). Exploring The Link Between Knowledge Sharing Enablers, Innovation Capability and Innovation Performance. International Journal of Innovation Management, 17(4), 1-20. https://doi.org/10.1142/S1363919613500187

Zahra, S.A., \& George, G. (2002). Absorptive Capacity: A Review, Reconceptualization, and Extension. Academy of Management Review, 27(2), 185-203. https://doi.org/10.2307/4134351

Zhang, M., Zhao, X., \& Lyles, M. (2018). Effects of Absorptive Capacity, Trust and Information Systems on Product Innovation. International Journal of Operations \& Production Management, 38(2), 493-512. https://doi.org/10.1108/IJOPM-11-2015-0687

Zou, B., Guo, F., \& Guo, J. (2017). Antecedents and Outcomes of Breadth and Depth of Absorptive Capacity: An Empirical Study. Journal of Management \& Organization, 1(9), 1-19. https://doi.org/10.1017/jmo.2017.29 


\section{Appendix:}

\section{Measurement items}

\begin{tabular}{|c|c|}
\hline Construct & Items \\
\hline $\begin{array}{l}\text { Absorptive } \\
\text { capacity } \\
\text { (AC) }\end{array}$ & $\begin{array}{l}\text { 1. We are successful in learning new things within our firm. } \\
\text { 2. Our firm is effective in developing new knowledge or insights that have the poten- } \\
\text { tial to influence our business. } \\
\text { 3. Our firm is able to identify and acquire internal (e.g., within the firm) and external } \\
\text { (e.g., market) knowledge. } \\
\text { 4. Our firm has effective routines to identify, value, and import new information and } \\
\text { knowledge. } \\
\text { 5. Our firm has adequate routines to analyse the information and knowledge ob- } \\
\text { tained. } \\
\text { 6. Our firm has adequate routines to assimilate new information and knowledge. } \\
\text { 7. Our firm can successfully integrate our existing knowledge with the new infor- } \\
\text { mation and knowledge acquired. } \\
\text { 8. Our firm is effective in transforming existing information into new knowledge. } \\
\text { 9. Our firm can successfully exploit internal and external information and knowledge } \\
\text { into concrete applications. } \\
\text { 10. Our firm is effective in utilising knowledge in new services. }\end{array}$ \\
\hline $\begin{array}{l}\text { Commit- } \\
\text { ment } \\
\text { to learning } \\
\text { (OLO1) }\end{array}$ & $\begin{array}{l}\text { 1. Managers basically agree that our firm's ability to learn is the key to our competi- } \\
\text { tive advantage. } \\
\text { 2. The basic values of our firm include learning as key to improvement. } \\
\text { 3. The sense around here is that employee learning is an investment not an expense. } \\
\text { 4. Learning in our firm is seen as a key commodity necessary to guarantee organisa- } \\
\text { tional survival. }\end{array}$ \\
\hline \begin{tabular}{|l} 
Shared \\
vision \\
(OLO2)
\end{tabular} & $\begin{array}{l}\text { 1. There is commonality of purpose in our firm. } \\
\text { 2. There is total agreement on our firm's vision across all levels, functions and divi- } \\
\text { sions. } \\
\text { 3. All employees are committed to the goals of our firm. } \\
\text { 4. Employees view themselves as partners in charting the direction of the firm. }\end{array}$ \\
\hline $\begin{array}{l}\text { Open- } \\
\text { mindedness } \\
(\mathrm{OLO} 3)\end{array}$ & $\begin{array}{l}\text { 1. We are not afraid to reflect critically on the shared assumptions we have made } \\
\text { about the way we do business. } \\
\text { 2. Personnel in our firm realise that the very way they perceive the marketplace } \\
\text { must be continually questioned. } \\
\text { 3. We continually judge the quality of our decisions and activities taken over time. } \\
\text { 4. Managers encourage employees to "think outside of the box." }\end{array}$ \\
\hline $\begin{array}{l}\text { Product } \\
\text { innovations } \\
\text { (ICA1) }\end{array}$ & $\begin{array}{l}\text { 1. Our firm often develops new products and services well accepted by the market. } \\
\text { 2. A great majority of our firm's profits are generated by the new products and ser- } \\
\text { vices developed. } \\
\text { 3. The new products or services developed by our firm always arouse imitation from } \\
\text { competitors. } \\
\text { 4. Our firm can often launch new products or services faster than our competitors. } \\
\text { 5. Our firm has better capability in R\&D of new products or services than our com- } \\
\text { petitors. } \\
\text { 6. Our firm always develops novel skills for transforming old products into new ones } \\
\text { for market. }\end{array}$ \\
\hline
\end{tabular}




\begin{tabular}{|c|c|}
\hline Construct & Items \\
\hline $\begin{array}{l}\text { Process } \\
\text { innovations } \\
\text { (ICA2) }\end{array}$ & $\begin{array}{l}\text { 1. Our firm often tries different operation procedures to hasten the realisation of } \\
\text { the firm's goals. } \\
\text { 2. Our firm always acquires new skills or equipment to improve the manufacturing } \\
\text { operation or service process. } \\
\text { 3. Our firm can develop more efficient manufacturing process or operation proce- } \\
\text { dure. } \\
\text { 4. Our firm can flexibly provide products and services according to the demands of } \\
\text { the customers. } \\
\text { 5. The new manufacturing process or operation procedure employed by our firm al- } \\
\text { ways arouses imitation from competitors. }\end{array}$ \\
\hline $\begin{array}{l}\text { Managerial } \\
\text { innovations } \\
\text { (ICA3) }\end{array}$ & $\begin{array}{l}\text { 1. Our firm will change the division of work among different departments according } \\
\text { to the needs of market management. } \\
\text { 2. Our firm's department heads will adopt new leadership approaches to lead all } \\
\text { staff towards task completion. } \\
\text { 3. The new staff welfare system adopted by our firm can effectively provide incen- } \\
\text { tives to our staff. } \\
\text { 4. The new financial management system adopted by our firm can effectively moni- } \\
\text { tor the actual discrepancy between our performance and our goals. } \\
\text { 5. Our firm emphasises innovative and creative capability when recruiting staff. } \\
\text { 6. The new staff recruitment system adopted by our firm is efficient and effective. } \\
\text { 7. The new performance assessment method adopted by our firm can enable depart- } \\
\text { ment heads to gain a better picture of how far the staff has achieved the firm goal. }\end{array}$ \\
\hline $\begin{array}{l}\text { Knowledge } \\
\text { donating } \\
\text { (KSd) }\end{array}$ & $\begin{array}{l}\text { 1. I often share with my colleagues the new working skills that I learn. } \\
\text { 2. My colleagues often share with me the new working skills that they learn. } \\
\text { 3. I often share with my colleagues the new information I acquire. } \\
\text { 4. My colleagues often share with me the new information they acquire. } \\
\text { 5. Sharing knowledge with my colleagues is regarded as something normal in my en- } \\
\text { terprise. }\end{array}$ \\
\hline $\begin{array}{l}\text { Knowledge } \\
\text { collecting } \\
\text { (KSc) }\end{array}$ & $\begin{array}{l}\text { 1. My colleagues often share with me the working skills they know when I ask them. } \\
\text { 2. I often share with my colleagues the working skills I know when they ask me. } \\
\text { 3. My colleagues often share with me the information they know when I ask them. } \\
\text { 4. I often share with my colleagues the information I know when they ask me. } \\
\text { 5. Our firm staff often exchanges knowledge of working skills and information. }\end{array}$ \\
\hline
\end{tabular}

Source: own study. 


\section{Author}

\section{Monika Stelmaszczyk}

The author holds a PhD in economics in management science and is assistant professor at the Jan Kochanowski University. Her research interests include strategic management, in particular organisational capabilities, managerial capabilities, organisational learning, and knowledge sharing. Correspondence to: Monika Stelmaszczyk, PhD, Jan Kochanowski University, Faculty of Law, Administration and Management, ul. Uniwersytecka 21, 25-406 Kielce, Poland, e-mail: m.stelmaszczyk@ujk.edu.pl

ORCID (1) http://orcid.org/0000-0002-7055-0193

\section{Acknowledgements and Financial Disclosure}

The article came into being within the project no. 614611 entitled "Determinants of dynamic capabilities in the context of organisational innovation - strategic resources perspective" and UJK Rector's grant no. 665012 financed by the Jan Kochanowski University conducted by Monika Stelmaszczyk in 2017-2019.

The author would like to thank the anonymous referees for their useful comments, which allowed to increase the value of this article.

\section{Copyright and License}

This article is published under the terms of the Creative Commons

Attribution - NoDerivs (CC BY-ND 4.0) License

http://creativecommons.org/licenses/by-nd/4.0/

Published by the Centre for Strategic and International Entrepreneurship - Krakow, Poland 